\title{
Bacteriological Analysis of Drinking Water Samples from Various Sources in Jammu
}

\author{
Ruchita Mahajan*, Kanishtha, Suharshi and Bella Mahajan \\ Department Of Microbiology, Government Medical College, Jammu, J\&K, India \\ *Corresponding author
}

\section{Keywords \\ Bacteriological analysis, \\ Drinking water samples}

Article Info

Accepted: 20 June 2018 Available Online: 10 July 2018

\section{A B S T R A C T}

Water pollution is a global problem and poses a serious threat to human life. The World Health Organization estimated that there are four billion cases of diarrhea each year in addition to millions of other cases of illness associated with the lack of access to clean water. This present study was designed to analyze the microbiological quality of the available drinking water from various sources in and around the area of Jammu. Drinking water samples were received in the Department of Microbiology occasionally through government district health authorities for the assessment of bacteriological quality of water from various public places in the interest of public health. A total of 152 water samples received from different sources (over head tank, well and tube wells, piped water taps, springs through spouts and household filter) from different parts of Jammu district were subjected for bacteriological analysis by MPN method. The total coliform count test was based on the multiple tube fermentation method to estimate the most probable number (MPN) of coliform organism in $100 \mathrm{~mL}$ of water for diagnosis of bacteriological contamination. . The results of MPN were interpreted based on McCrady's probability tables. A total of 152 water samples were received from different water sources (tap water $=65$, tube wells $=43$, over head tank $=10$, restaurants $=15$ and household filter $=19$ ) in Jammu District in the Department of Microbiology during the year 2017/2018. Of the tested samples, 35(23.02\%) were excellent ,21 (13.81\%) were satisfactory, $08(5.26 \%)$ were suspicious and $88(57.89 \%)$ were unsatisfactory according to McCrady's probability chart. Also distribution of presumptive coliform count in relation to the different sources was studied. The present study assessed the bacteriological quality of water in different drinking water sources in the district of Jammu; $57.89 \%$ of the samples were found to be unsatisfactory and unfit for human consumption. Of all the samples tested only 51/152 $(33.55 \%)$ were found to be excellent even after the inclusion of household filtered waters. Such high percentage of unsatisfactory water samples calls for public awareness, immediate attention, and action by the authorities. A comprehensive development program must include a practical and cost-effective approach to provide potable water and a more aggressive approach to reduce the risk of water-related transmission of diseases. 


\section{Introduction}

Water pollution is a global problem and poses a serious threat to human life. The World Health Organization estimated that there are four billion cases of diarrhea each year in addition to millions of other cases of illness associated with the lack of access to clean water. More than three million people in the world die of water-related diseases due to contaminated water each year, including 1.2 million children(1).

The safety of drinking water can be monitored in a number of ways because the constituents of drinking water (such as chemicals and microbes) which can compromise human health can be measured directly. The reason for monitoring drinking water quality is to determine whether the water supply system is being operated correctly, implying that the water is safe for drinking or not. Indicator microorganisms survive better and longer than the pathogens with a uniform and stable properties and may easily be detected by standard laboratory techniques.

It is well established that infectious diseases are transmitted primarily through water supplies contaminated with human and animal excreta, particularly feces. The human pathogens that present serious risk of disease whenever present in drinking water include Salmonella spp., Shigella spp., pathogenic Escherichia coli, Vibrio cholerae, Yersinia entercolitica, Campylobacter spp., various viruses such as hepatitis $A$, hepatitis $E$, rotavirus and parasites such as Entamoeba histolytica and Giardia spp. (2) Hence, it is essential to check the quality of the available drinking water from various sources. In view of this present study was designed to analyze the microbiological quality of the available drinking water from various sources in and around the area of Jammu.

\section{Materials and Methods}

Drinking water samples were received in the Department of Microbiology occasionally through government district health authorities for the assessment of bacteriological quality of water from various public places in the interest of public health. A total of 152 water samples recieved from different sources (over head tank, well and tube wells, piped water taps, springs through spouts and household filter) from different parts of Jammu district were subjected for bacteriological analysis by MPN method. Samples were collected aseptically in $300 \mathrm{ml}$ sterile screw capped bottles and immediately transported to department of microbiology for processing. The samples were transported and stored strictly in accordance with the procedures and guidelines described in the WHO's guidelines for drinking water quality (3).

Water samples containing residual chlorine were neutralized by adding pre-sterilized 0.1 $\mathrm{mL}$ sodium thiosulphate $(1.8 \% \mathrm{w} / \mathrm{v})$ per 100 $\mathrm{mL}$ of water sample. The samples were stored at $2^{\circ} \mathrm{C}-8^{\circ} \mathrm{C}$ in a dark area to avoid changes in bacterial count until analysis. The total coliform count test was based on the multiple tube fermentation method to estimate the most probable number (MPN) of coliform organism in $100 \mathrm{~mL}$ of water for diagnosis of bacteriological contamination.

The test was carried out by inoculation (for 48 hours at $35^{\circ} \mathrm{C}$ ) of measured quantities of sample water $(1.0,10,50 \mathrm{~mL})$ into tubes of double- and single strength MacConkey's lactose bile salt broth with bromocresol purple as an indicator. The tubes showing gas formation and change in colour were considered to be presumptive coliform positive. The results of MPN were interpreted based on McCrady's probability tables from the number of tubes showing acid and gas (fermentation by coliform organisms) to define the sample as satisfactory or 
unsatisfactory. (4) All the media and reagents were procured from Himedia, Pv Ltd., Mumbai, India.

\section{Results and Discussion}

A total of 152 water samples were received from different water sources (tap water $=65$,tube wells $=43$, over head tank $=10$, restaurants $=15$ and household filter $=19$ ) in Jammu District in the Department of Microbiology during the year 2017/2018. Table 1 shows the distribution of water collected from different sources.

These samples were tested for the presence of coliform bacilli using presumptive coliform test. Of the tested samples, 35(23.02\%) were excellent, $21(13.81 \%)$ were satisfactory, 08 $(5.26 \%)$ were suspicious and $88(57.89 \%)$ were unsatisfactory according to McCrady's probability chart. Table 2 depicts the presumptive coliform count of the samples received in the laboratory.

Since most of the samples tested were found to be unsatisfactory, source wise distribution of the unsatisfactory samples was done which is shown in Table 3. Out of the 65 samples taken from tap water, 42 were found to be unsatisfactory. Also 30/43 from tubewell, 04/ 10 from over head tank, 02/15 from restaurants, 01/ 19 from household filters were found to be unsatisfactory.

Table.1 Distribution of water collected from different sources

\begin{tabular}{|l|l|c|}
\hline Serial No. & Source of water collection & $\begin{array}{c}\text { Number of Samples } \\
\text { Collected }\end{array}$ \\
\hline $\mathbf{1 .}$ & Tap water & 65 \\
\hline $\mathbf{2 .}$ & Tube well & 43 \\
\hline $\mathbf{3 .}$ & Over head tank & 10 \\
\hline $\mathbf{4 .}$ & Restaurants & 15 \\
\hline $\mathbf{5}$ & Household filters & 19 \\
\hline
\end{tabular}

Table.2 Presumptive coliform count of the samples tested

\begin{tabular}{|l|l|c|c|}
\hline & $\begin{array}{l}\text { Grade of } \\
\text { Water samples } \\
\text { tested }\end{array}$ & $\begin{array}{c}\text { Presumptive } \\
\text { Coliform Count Per } \\
\mathbf{1 0 0} \text { ml }\end{array}$ & $\begin{array}{c}\text { Number(Percentage) of } \\
\text { Water Samples Out of 152 }\end{array}$ \\
\hline $\mathbf{1}$ & Excellent & 0 & $35(23.02 \%)$ \\
\hline $\mathbf{2}$ & Satisfactory & $1-3$ & $21(13.81 \%)$ \\
\hline $\mathbf{3}$ & Unsatisfactory & $4-10$ & $88(57.89 \%)$ \\
\hline $\mathbf{4}$ & Suspicious & $>10$ & $08(5.26 \%)$ \\
\hline
\end{tabular}

Table.3 Number of total and unsatisfactory samples from different sources

\begin{tabular}{|l|c|c|}
\hline Source & Total Sample Received & Samples Found Unsatisfactory \\
\hline Tap water & 65 & 42 \\
\hline Tube well & 43 & 30 \\
\hline Over head tank & 10 & 04 \\
\hline Restaraunts & 15 & 02 \\
\hline Household filters & 19 & 01 \\
\hline
\end{tabular}


Table.4 Distribution of presumptive coliform count in relation to the different sources

\begin{tabular}{|l|c|c|c|c|}
\hline Source & $\begin{array}{c}\text { Excellent } \\
(0)\end{array}$ & $\begin{array}{c}\text { Satisfactory } \\
(1-3)\end{array}$ & $\begin{array}{c}\text { Suspicious } \\
(4-10)\end{array}$ & $\begin{array}{c}\text { Unsatisfactory } \\
(>10)\end{array}$ \\
\hline Tap water & 13 & 04 & 06 & 42 \\
\hline Tube well & 10 & 03 & 00 & 30 \\
\hline Over head tank & 03 & 01 & 02 & 04 \\
\hline Restaraunts & 08 & 04 & 01 & 02 \\
\hline Household filters & 14 & 03 & 01 & 01 \\
\hline
\end{tabular}

Also distribution of presumptive coliform count in relation to the different sources was studied (Table 4). It was found that out of the 65 tap water samples received, 13 were excellent,04 satisfactory,06 suspicious and 42 were unsatisfactory. From the tubewells 10 were excellent, 03 satisfactory and 30 unsatisfactory. Maximum number of excellent samples was received from household filters.

The provision of effective sanitation programs and access to safe drinking water have been a major problem for many developing countries. In the developing world, especially in remote rural areas and industrial areas, over three million deaths per year are attributed to waterborne diarrheal diseases, especially among infants and young children in poor communities (5). It has been estimated that water, sanitation, and hygiene are responsible for $40 \%$ of all deaths and $5.7 \%$ of the total disease burden occurring worldwide (6). The present study assessed the bacteriological quality of water in different drinking water sources in the district of Jammu; $57.89 \%$ of the samples were found to be unsatisfactory and unfit for human consumption. The results are found to be consistent with the various other studies conducted in the same setting, which found $47.5 \%$ and $38.6 \%$ of samples, respectively, to be unsatisfactory $(7,8)$.

Concordant findings were also reported from studies done in different settings of northern India $(9,10)$.
Of all the samples tested only 51/152 (33.55\%) were found to be excellent even after the inclusion of household filtered waters. This indicated that the drinking water quality has not been improved well during last twenty years period despite of various efforts put. This could be due to the population growth, unplanned urbanization, poverty and others.

In the present study, $64.61 \%$ of the natural tap water samples were unsatisfactory for drinking. This appears to be contamination with human and animal excreta. This indicates of open defecation, and needs to make the people aware of using toilet.

It was further observed in our study that the MPN of all the water sources was higher in the rainy seasons as compared to winter and summer. These results were in concurrence with the findings of Mohopatra et al., who reported that coliform counts in two water channels in Delhi had the lowest values in the month of December (11). Jais et al., reported the highest coliform counts in the months of June and July (12).

The consumption of drinking water contaminated with pathogenic microbes of faecal origin is a significant risk to human health in the developing world, especially in remote rural areas and peri-urban ' shanty' communities. A report quoting the WHO stated that more people would die from consuming unsafe drinking water and unsanitary conditions by the year 2020 than would die from AIDS if 
steps to improve water quality were not taken at this point in time (13) Such high percentage of unsatisfactory water samples calls for public awareness, immediate attention, and action by the authorities. A comprehensive development program must include a practical and costeffective approach to provide potable water and a more aggressive approach to reduce the risk of water-related transmission of diseases.

\section{References}

1.World Health Organization and the United Nations Children's Fund (2000) Global water supply and sanitation assessment, 2000 report. Available: http://www.who.int/water_sanitation_he alth/monitoring/globalassess/en/.

2.Geldreich EL (1992) Water borne pathogens invasions: A case for water quality protection in distribution. Proceedings of American Water Works Association. Water Quality Technology Conference: 1-18.

3.World Health Organization (2010) Guidelines for drinking water quality. Available: http://www.who.int/water_sanitation_he alth/dwq/gdwq3rev/e n/. Accessed 8 June 2012.

4. Tillet HE (1987) Most probable number of organisms: Revised tables for multiple tube methods. Epidemiol Infect 99: 471476. 11

5 Kumar D, Malik S, Madan M, Pandey A (2013) Bacteriological analysis of drinking water by MPN method in a tertiary care hospital and adjoining area Western UP, India. J Environ Sci 4: 1722. 15
6 Pruss A, Kay D, Fewtrell L, Bartrem J (2002) Estimating the burden of disease due to water, sanitation and hygiene at global level. Environ Health Perspect 110: 537-542. 14

7 Malhotra S, Arora U, Devi P (2009) How safe is the safe water supply? Internet $\mathrm{J}$ Microbiol 7: 1-7

8. Jindal N, Singh S, Arora S (1991) A study of coliform bacteria isolated from drinking water. Indian J Med Microbiol 9: 162$163[17,18]$.

9. Kumar D, Malik S, Madan M, Pandey A (2013) Bacteriological analysis of drinking water by MPN method in a tertiary care hospital and adjoining area Western UP, India. J Environ Sci 4: 1722. 15

10.Goel S, Sood R, Mazta S, Bansal P, Gupta A (2007) Bacteriological quality of water samples of a tertiary care medical centre campus in North West Himalayan region of India. Internet $\mathbf{J}$ Third World Med 4: 5

11. Mohapatra SP, Saxena SK, Ali A (1997) Occurrence of coliform bacteria in channels receiving municipal sewage. Indian J Environ Protect 12: 161-169

12. Jais GK, Shrivastava RM, Jain OP, Shrivastava PK (1993) Bacteriological Quality of Drinking Water in and around Vijaipur. Indian $\mathbf{J}$ Environ Protect 13: 758-760.

13. Goel S, Sood R, Mazta S, Bansal P, Gupta A (2007) Bacteriological quality of water samples of a tertiary care medical centre campus in North West Himalayan region of India. Internet $\mathbf{J}$ Third World Med 4: 5.

\section{How to cite this article:}

Ruchita Mahajan, Kanishtha, Suharshi and Bella Mahajan. 2018. Bacteriological Analysis of Drinking Water Samples from Various Sources in Jammu. Int.J.Curr.Microbiol.App.Sci. 7(07): 2795-2799. doi: https://doi.org/10.20546/ijcmas.2018.707.326 